\title{
A New Wing of Production Function of Natural Resources Management - Divergence of Beneficial Services for Fostering People's Voluntary Adoption of Innovations and Practices
}

\section{RC Yadav*}

Former Head, ICAR - CSWCRTI, Research Centre, Agra, Uttar Pradesh, India

*Corresponding Author: RC Yadav, Former Head, ICAR - CSWCRTI, Research Centre, Agra, Uttar Pradesh, India.

Received: September 26, 2019; Published: November 11, 2019

DOI: 10.31080/ASAG.2019.03.0718

\begin{abstract}
A production function was introduced and patternised for various natural resources management project in general and watershed management, in particular, in arlier endeavours. Recently, an innovation research entitled,'Eceo zero weeding agricutre”, was created. The zero weeeding agricultue produces multiple benefits, which prompted to add as a new wing in the patternised production function to make it as auto adoption of technologies of natural resources amangement. New concept of convergence of services vis a vis divergence of obenfits are intoduced and added as a new wing to the production function. Case study of innovation of eco zero weeding is presented, which produces multiple benefits and remains as panacea shrine for total solutions in agriculture. These benefits give an automotaion in the practice which will bring prosperity, livable healthy environment and social harmony among people. The eco zero weeding eliminates several risks involved in out door agricultural orduos field works. Thus, this innovation supercedes the Rogers theory of adoption of innovation, which identifies different groups of innovation adopters, as it is getteing atomatically adopted by it self and comes in to action for producing benfits.

Keywords: Innovation; Rogers Diffusion Theory; Exention of Technologies; Eco-Zero Weeding; Harmony among People; Natural Resources Management
\end{abstract}

\section{Introduction}

Agriculture has been basic activity of producing food chains right from its inception in the ancient history. The crops perform process of photosynthesis that forms carbohydrate and oxygen. In the process the carbohydrate is again used in nitrogen fixation that is utilized again for plant growth in the form of polymerized crop leaf, stem, flowers and production of fruits and grains. The intensification in agriculture produced huge volume dried agricultural tissues, popularly called straw-residue which encompasses many unpleasant products and gases having implication in environment pollution.
For any enterprise management various functional factors were organised in logical patteren (Figure 1), which was highly convincing and adopted in many scenarios of developments [1-7]. The production functiosn Figure 1 (unshaded part of the Figure 1) served up to convergence of services in watershed managementprojects. This convergence sought cooperation and support of services of line departments to facilitate budget support and deparmental cooperations, which capitalises judicious use of natural resources under unified action of watershed management. The production function had been used in such projects on watershed management for almost over three and half decade (1980--2017). 


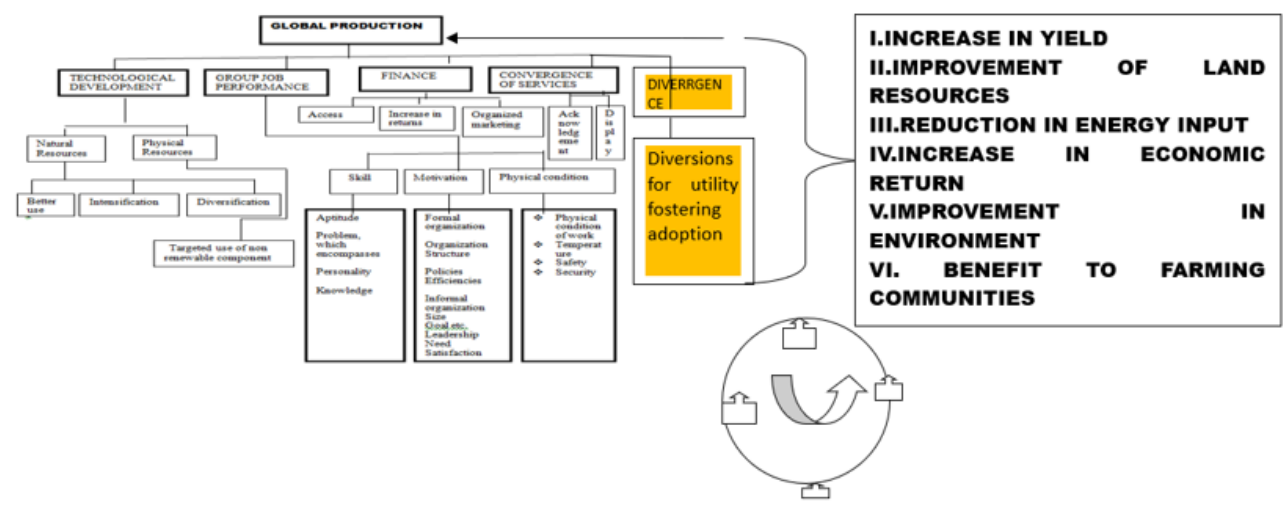

Figure 1: The production factors involved in natural resources management systems and the multiple benefits of eco- zero weeding.

The concept of creating a novel feasible technology being efficient, effective impact producing and sustainable for easy adoption. The concept was fully substantiated by a novel technology of Eco zero weedding elaborated in detail in studies [13-18]. The eco zero weeding has been documentd on various aspects as new benefit of the eco zero weeding is further devised to overcome desertification. The $\mathrm{N}$ fixed by eco zero weeeding enhances cation Exchange capacity (CEC) of soil. $\mathrm{N}$ is the most (13) dominating controller of plant nutrient absorption by attracting plant nutrients with positive ions. With this enhancement the eco-zero weeeding has taken a form of nanotechnology with practically non monetary in put in management of natural resources viz land which is getting degraded and undergoing desrtification. This nanaotechnology is a exact, perfect solution to degradation and combating desertification.

The objective of this study was to set requirements that enables it render liable to auto adoption of technology. The technology has to be relevant, effective, efficient and sustainable.

\section{Materials and Methods}

The eco-zero weeding

In the eco zero weeding a new concept of ecobalance was created where in Nitrogenfixing crrop is sown in the solecrops of interest. The leguminous nitrogen fixing crop was sown at ddifferent ratesof sole crop of pulse crop. The eco which produced the highest yield of crop was designated as the eco-zero weeding practice.
In the ecozero weeding the objective is not to bring the weeds to zero level ie fully weed free, but get level of yeld where the yield of desired crop is the maximum. In the experimentation under field and practically possible method is to conduct experiment with successesive increaing levels of seeding of the eco crop viz no crop as control ie $0 \%, 25 \%, 50 \%, 75 \%, 100 \%$ and $125 \%$ and noweedings were performed. The crop yield so obtained at different level of seed rates of the selected eco crop is optimised with six point sets of seed rate eco and yieldq/ha, to strike the optimum level of seed rate sown and eco estblished. Such field sudies were conducted for garlic and onion.

\section{Divergence of benefits}

The nature based eco zero-weeding innovative practice was developed which acts as panacea shrine for total solution in agriculture [8-12]. The eco zero weeding replaces any kind of measure so far thought over and praciced viz manual, mechnical, hand and automaton, chemical and weedicide based weed management. The eco zero weeding not only supresses weeds to overcome crop yield losses, but in addition it, enhances yield of crpp to an unimanable level. This technological breakthrough has create numerous benefits. The eco zeoweeding is practical, non monetary input involving measure, hence its adoption by the people will spread by word of moth, who have harnessed the benefits. A futher development has been added to make it as a new wing of "Divergence of services", which makes the practice as itself auto driven function. The conceptual details of the new wing is as under. 


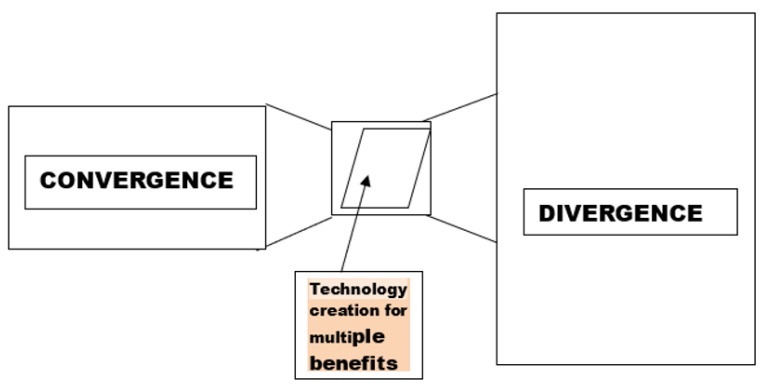

Figure 2: Conceptual diagram of convergence and divergence of benefits from a technology.

(Note convergence of services is small, but diveregence of benefit is very large due to magnications in results of technological natural resources management).

Characterizing of technologies to get qualified to be auto adoption

A technology should be sipple to come to knowledge of adopeters, itshould be organizable with locally available matereials. It should be least cost involving, relevant and problem solving, effective, efficient, and sustainable. It should aalso produce multiple benefits producing, meetin all requireemnts oe strength, weakness, opportunity and threats (SwOT) analysis. The case of eco zero weeding had been evaluated and scaled down to fulfill such manadatory requirements.. These aspects will be presented in the result part of the study.

\section{Results and Discussion}

The conceptual Figure 2 is devised to fortify convegence of services that will help develop projects on natural resources management, wiz watershed management and the interactive result will get enlarged to many folds. This result will have potential to be harnessed in divergence of benefits for the various beneficiaries dependent on the land resources. Thus, it will bring lot of facility and prosperity for the society, people and the Government that will prompt people to adopt the production technology by them self.

The technology of eco-zeo weeding is presented as case to support view point of divergence of benefits, the new wing in Figure 1, Addendum to Figure 1 (Shaded part) ie result will get enlarged to many folds. This result will be shared by various beneficiaries dependent on the land resources.

In the eco zero weeding a new concept of ecobalance was created where in Nitrogen fixing crop is sown in the sole crops of interest. The leguminous nitrogen fixing crop should be sown at ddifferent rates of sole crop of pulse of the season in any region. The eco which produced the highest yield of crop was designated as the eco zeo weeding practice. In the eco zero weeding the objective is not to bring the weeds to zero level ie fully weed free, but get level of yield where the yield of desired crop is the maximum.. In the experimentation under field and practically possible method is to conduct experiment with successesively increaing levels of seeding of the eco crop viz no crop as control ie $0 \%, 25 \%, 50 \%, 75 \%, 100 \%$ and $125 \%$ and no weedings were performed. The crop yield so obtained at different level of seed rates of the selected eco crop is optimised with six point sets of seed rate eco and yield, $\mathrm{q} / \mathrm{ha}$, to strike the optimum level of seed rate sown and eco estblished. Such field sudies were conducted for garlic and onion $[9,12]$. The incredible innovative technology of eco-zero weeding has produced multibenefits and proved as panacea shrine for total solution in agriculture, This innovative scientific development by the author $[9,11,12]$, proved to be of immense value and surpassing any known scientific innovation on weed contol or management. This new innovation saves crops losses and robbing natural resources vix solar light, fresh air, soil moisture etc but also inhances unimaginable yields of crops and bring several other benefits. This innovative technological breakthrough inspired to create new wing of divergence of benefits. As it produces multiple benefit due to its action in different direction, as signified by symbol interaction ( $\square$ ) was added after the convergence of services with nomenclature of divergence of benefits, which signifys intereactive function. There will be several example cases to cite, that will prosper in the domain of natural resources management. Additional note substantiates the interacthins in developmet of novel technology.

This new wing (Shaded part in Figure 1) adds a new feature for attracting natural resources management as an example case of eco-zero weeding agriculture. It has inbuilt mechanism to make irrotational movement so that sustainability is maintained for all the time [14]: 
- $\quad$ The eco zero weeding increases yield to unimaginaly high level.

- It improves soil nutrients season after season by enrichinh residul plant nutrients in the soil after harvest of crops.hence, eliminates occurrence of land degradation due to nutrient defficiency..

- It reduces washoff erosion due to green soil surface cover.

- It works continuousyly suppressing weeds and continues $\mathrm{N}$ fixation under all good and abarrant weather conditions.

- It eliminates need of any post sowing tillage viz secondary tillage for soil aeration or for weed control..

- Its successful working acts as crop insurance, hence there occurs stability in market price.

- Good and sustainable producition facilitates harmony among people and effective trustworthy socio political governance.

- The ecozero weeding becomes a nanotechnology for combating desertification.

- It has surpassed requirements of an ideal technology and that resired for SWOT analysis.

- It is very relevant for weed contol/management, eco friendly, nocarbon foot print creating, eco friendly,, effecive, efficientan and sustainable. The documentation has proven as a useable science tht will bring multiple benefits.

With considerations of aforementioned qualities, the ecozero weeding works as a technology of autoadoption by words of mouth., witout need of extra expensive extension serices of agricultural technologies.

The benfits are fully developed and substantiated in several research publications [14-19]. Divergence of benefits will charter auto adoption of innovative technology of natural resources conservation -the ecozero weeding agriculture and many alike technology and practices for people's adoption $[19,20]$.

This automation over takes many theoretical development viz. Rogers,s theory of diffusion of innovation [20,21]. Rogers [20] devised theory of diffusion of technology adoption classes vix early adopters, early majority, late majorit and laggard. The new development of nanotechnology fosters its fast adoption by early majority as it is a non moneatary input involving nanaotechnology based on most exact scientific principle. This is a technolology for combating land desertification by enabling productivity of soil. The technology should be so lucrative that it will strongly attracts all classes of technology adopters for adoption of innovations. It is highly prospecting measure to prompt peoples' adopt new innovation $[17,18]$ of natural resources management that will inturn build good livable environment, land resources conservation, cultivate peoples' harmony, develop stable markets and create good governanace. The new wing will reduces burden of extension [20,21].

Once principle or theory of innovative technology is developed, it will form a universally applicable policy tool to bring solution to problems at any time and place in the global scenario. The factors interaction will result another route of the same policy tool. The local shortfalls can be made up by customized experimentations in any locality. Thus, Figure 3 depicts importance of theory and local experimentation. Theory based policy too brings quick solution and local researches will bring the doses of treatments. Thus, adoption of both the routes will bring economy in research for resources conservation. The cases of adoption of innovations have already been covered. Thus, this research makes all nations conduct local research at their own level with limited resources and solve their problems. This style of functioning will create intellectual properties for the nations.

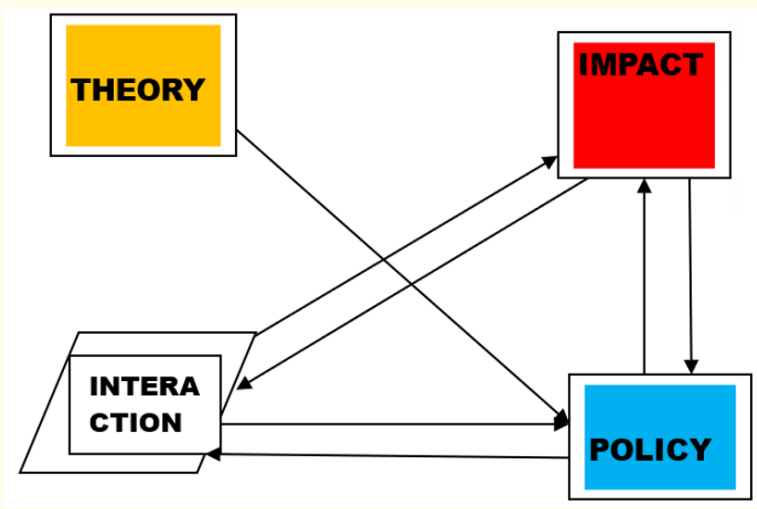

Figure 3: Network of theory, policy tool vs driving factors impact and policy tools.

\section{Conclusion}

The study adds a new wing that prompts its auto adoption by rhe user groups. The study recommends that any technologiical 
innovation should also be gauged for its capability of enabling its auto adoption. The eco zero weeding fulfills all necessary requirements and accolplishing multiple benefits that makes it as an exemplary case of new wing in the production function. Thus, this study has objectively accomplished its worthyness as new wing in production function., which sets guideline for weighing and rating of innovations in agriculture.

\section{Acknowledgements}

The author duly acknowledges sources and references cited in support of statements made in the manuscript. No funding source was available for this study.

\section{Conflict of Interest}

It is declared that there exists no any financial conflict or any conflict of authorship.

\section{Bibliography}

1. Yadav RC and Bhushan LS. "Watershed management redefined". Journal of Soil Conservation (2000).

2. Yadav RC and Bhushan LS. "Paradigm of participatory watershed management for sustainability: Principles and practices. ICTWRM-2000)". Proceedings of international conference on integrated water resources management for sustainable development. 19-21 December, New Delhi, India (2000): 976988.

3. Yadav RC and Bhushan LS. "Conservation of gully susceptible riparian areas in the deep alluvial soil region". Land Degradation and Development. U.K. 13 (2002): 201-219.

4. Yadav RC. "Innovative application of scientific facts for nutrient recovery from waste water streams for sustainable agriculture and protection of environment: A Review". Hydrology Current Research USA 3 (2012): 1-11.

5. Yadav RC. "Racy nature agriculture versus alike other technologies: A technology contrast". Agriculture and Environmental Sciences. Dubai. 13 (2013): 1412-1439.

6. Yadav RC. "Innovative application of scientific facts or arresting GHG N2O -and improvising lucrative ventures with enhanced land water and nutrient use efficiency". Journal of Energy and Environmental Science Germany 128 (2014): 486-520.

7. Yadav RC and Chaudhary MP. "Racy nature- A sun technology towards quantum agriculture”. World Journal of Agricultural Research 2 (2014): 223-227.

8. Phillip Ardagh. "WOW- Discoveries that changed the world". Mac Milan Children's Book. Mac Millan, U.K (2000).
9. Yadav RC. "Eco-zero weeding agriculture to produce exemplary yield of onion- A corroborative study. Innovative Technology in agriculture". Scientia Ricerca-USA 1.5 (2017): 234-245.

10. Yadav RC. "Development of universal ultimate green chemistry and eco agric for sustainable productivity". (2018).

11. Yadav RC. "Eco-zero weeding: a wow incredible innovation for altering things around us and India inaction". World Journal of Agricultural Research 6 (2018): 94-104.

12. RC Yadav. "New innovative technology for producing exemplary yield of garlic and onion". Innovative techniques in Agriculture Scientica Ricerca 1 (2017): 192-204.

13. Yadav RC. "Prospecting nanotechnology of eco-zero weeding agriculture for enhancing yield and combating desertification Land degradation and development U.K. 2019".

14. Rammrutham S. "Hydraulics, Fluid Mechanics, and Hydraulic Machines”. Dhanpat Rai Publishing Co., New Delhi (2008): 252.

15. Yadav RC. "Biological nitrogen harvesting from aquatic ecosystem-A A new scientific vision". Fisheries in Aquaculture Journal USA 5 (2014).

16. Yadav RC. "Ultimate green irrigation practice by innovative application of scientific facts". World Journal of Agronomy and Food Science and Technology U.S.A 2 (2015): 1-30.

17. Yadav RC. "Practice for intercropping and making shortfalls in pulse productivity and reduction of green house gas nitrous oxide". Archives in Chemical research USA. 1 (2017): 10.

18. Bossier D and Geheb K. "Conserving land, Protecting water". An introduction. In Bossio and Geheb. Eds. Conserving land protecting water. In: Geheb, D and GEheb, Kim. Eds. Comprehensive assessment in agriculture. Series CABI in association with CGIAR Challenge Programme on water and food. International Water Management Institute. Sri Lanka (2008).

19. Parkinson C Northcote and Rustom Ji MK. "Realities in management”. India Book House Pvt Ltd. (1993): 80-103.

20. Rogers E. Diffusion of innovations. New York press. 5th Edition (2004).

21. Yadav RC., et al. "Prospecting technical human resources for infrastructure development and resource conservation. Management of science and engineering management". Academic Press, England, U.K (2012).

Volume 3 Issue 12 December 2019 (C) All rights are reserved by RC Yadav. 